\title{
Towards genetic engineering of maritime pine (Pinus pinaster Ait.)
}

\author{
Jean-François Trontin*, Luc Harvengt, Elizabeth Garin, Manuel Lopez-Vernaza, \\ Lydia Arancio, Josiane Hoebeke, Francis Canlet and Marc Pâques
}

AFOCEL, Laboratoire de Biotechnologie (biotech@afocel.fr), Domaine de l’Étançon, 77370 Nangis, France

(Received 1 September 2001; accepted 22 January 2002)

\begin{abstract}
Using our improved protocols for somatic embryogenesis in Pinus pinaster, transgenic tissues and plantlets were recovered after microprojectile bombardment (biolistic) or cocultivation of embryonal-suspensor masses (ESM) with Agrobacterium tumefaciens. Transformation experiments were carried out with selectable hpt gene (hygromycin B resistance) and reporter gus gene ( $\beta$-glucuronidase activity). With both methods, hygromycin was shown to be an effective selective agent of transformed cells within 4-19 weeks. The mean number of hygromycin-resistant lines expressing gus per gram ESM subjected to DNA transfer, ranged from 7.0 to 8.5 using biolistic and 0 to 67.3 during Agrobacterium experiments. Mature somatic embryos obtained from some transformed lines were converted into plantlets and grown in the greenhouse. The whole process (from transformation to plant acclimatisation) could be completed within only 12 months. The transgenic state of ESM, somatic embryos and plants was confirmed by histochemical GUS assays and molecular methods.
\end{abstract}

Pinus pinaster / somatic embryogenesis / biolistic / Agrobacterium tumefaciens / transgenic plant

Résumé - Transformation génétique du pin maritime (Pinus pinaster Ait.). En appliquant nos protocoles d'embryogenèse somatique développés pour Pinus pinaster, des tissus et plantes transgéniques ont été obtenus après bombardement avec des microparticules (biolistique) ou coculture de masses embryonnaires (ESM) avec Agrobacterium tumefaciens. Les expériences de transformation ont été conduites à l'aide du gène de sélection hpt (résistance à l'hygromycine B) et du gène rapporteur gus (activité $\beta$-glucuronidase). L'hygromycine a permis de sélectionner efficacement les cellules transformées par ces deux méthodes en 4 à 19 semaines. Le nombre moyen de lignées résistantes à l'hygromycine exprimant le gène gus obtenu par gramme d'ESM varie de 7,0 à 8,5 (biolistique) ou de 0 à 67,3 (Agrobacterium). Les embryons matures obtenus à partir de certaines de ces lignées ont pu être convertis en plantules élevées en serre. Seulement 12 mois sont nécessaires de la transformation des ESM jusqu'à l'acclimatation des plantes. La nature transgénique des ESM, embryons somatiques et plantes, a été confirmée à l'aide de tests histochimiques «GUS » et de méthodes moléculaires.

Pinus pinaster / embryogenèse somatique / biolistique / Agrobacterium tumefaciens / plante transgénique

\section{INTRODUCTION}

Maritime pine (Pinus pinaster Ait.) is a highly valuable coniferous species (Pinaceae) originating from the Mediterranean region. Five major geographic races are generally recognized: the Atlantic coast group from Portugal to France, the Mediterranean coast group from Spain to Italy, the Corsican group restricted to Corsica and Sardinia, the Continental group located in the Iberian and Morocco mountain regions and the North Africa coastal group from Algeria to Tunisia. Extensively planted, it covers more than 4 millions ha in Europe and has been widely established in non- native areas such as South Africa, South America, New Zealand and Australia over the last century. Moreover, it is planned to plant about 500000 ha in some low rainfall zones of Australia in the next 20 years [7].

In France, maritime pine covers about 1.4 millions ha mainly located in the Landes forest and represents the first coniferous species used for reforestation and afforestation. Each year, up to 18000 ha are established and about 9 millions cubic meters are harvested (1/3 for pulpwood and 2/3 for sawlogs and peelers).

In conjunction with other French forest research organisations, AFOCEL has initiated and developed in the early

* Correspondence and reprints

Tel.: +33 1 60670032; fax: +33 1 60670256; e-mail: trontin@afocel.fr 
1960s a long-term breeding program of maritime pine to improve wood supply, stand productivity, and to benefit forest owners. 1570 selected trees from the Landes and Corsica provenances are currently under evaluation (128 ha of progeny tests) to define a third set of breeding materials and their production method (seed orchards). Using Landes $\times$ Landes and Landes $\times$ Corsica second-generation selections, it has been estimated that genetic gains were about $16 \%$ in volume and $20 \%$ for stem form, similar to that obtained for the first generation selections [8].

Vegetative multiplication of maritime pine using in vitro techniques such as micrografting [15], micropropagation [14] and somatic embryogenesis [3] is a more recent deployment option that has been developed by AFOCEL. This is expected to have the advantage of overcoming our shortage of selected, high quality material. But, more importantly, vegetative propagation is a very effective way to capture the best genetic stock from the breeding program. Compared to horticultural cuttings usually subjected to decreased rooting with ageing, in vitro biotechnology is considered to have greater potential for sustained clonal propagation at lower cost, especially the most powerful somatic embryogenesis technique coupled with long-term frozen storage to preserve juvenility $[34,42,45]$. Since our initial work [3], significant improvement of protocols from initiation of embryonal-suspensor masses (ESM) to maturation of somatic embryos have been obtained [28, 36, 37].

In maritime pine as in others conifers, somatic embryogenesis is still difficult to achieve in material beyond the seedling stage (immature zygotic embryo) but some progress in rejuvenation was recently published for radiata pine [40] and Picea abies [18]. This strategy is increasingly combined with tree improvement programs to allow rapid build-up of stocks for genotype selection trials and propagation of elite material [1, 11, 20, 31, 44].

Such a promising tissue culture system undeniably provides a good target for stable genetic transformation of conifers such as larch [23, 29], spruce [10, 48, 49], and pine [6, 30, 47] and offers new prospects for rapid and efficient introduction of desirable traits, mostly unknown (e.g. pests and herbicide tolerance) or with low heritability (e.g. wood quality, vigour, frost tolerance) in selected maritime pines. Moreover, efficient transformation procedure will be advantageous for studying metabolic pathways and for validation of candidate gene approaches of quantitative trait loci required for marker-assisted selection.

The main objective of this work was to demonstrate that stable genetic transformation of maritime pine elite genotypes is conceivable. Based on the expertise of AFOCEL on somatic embryogenesis [3, 36, 37], we used ESM initiated from selected seeds as target tissues for transformation experiments to produce transgenic maritime pines. Two different methods commonly used for successful transformation of plants were independently evaluated: (i) the microprojectile bombardment technique (biolistic) using our affordable method previously developed for Picea abies [4] and (ii) a modification of the Agrobacterium tumefaciens-mediated protocol established by Levée et al. [30] to transform Pinus strobus. In this pilot project, we used the hpt gene encoding hygromycin phospho-transferase that confers resistance to the antibiotic hygromycin B as a selective agent of transformed cells [46], and uidA (gus) gene encoding the $\beta$-glucuronidase activity as a reporter of gene expression [21]. To our knowledge, this is the first report on successful regeneration of transgenic Pinus pinaster.

\section{MATERIALS AND METHODS}

\subsection{Plant material}

Label and origin of ESM lines used for transformation experiments are indicated in table I. Most lines belonged to unrelated full-sib or half-sib seeds families produced in the frame of the maritime pine-breeding programme. ESM were initiated from immature zygotic embryos according to the method of Bercetche and Pâques [3] and weekly subcultured in the dark $\left(25 \pm 1{ }^{\circ} \mathrm{C}\right)$. ESM maintenance and plantlet regeneration were done according to Ramarosandratana et al. $[36,37]$. Petri dishes are sealed with two rounds of cling film.

\subsection{Plasmid vectors and Agrobacterium strain}

During biolistic experiments, we used a co-transformation procedure of maritime pine ESM with gus and hpt genes located on two distinct plasmid vectors respectively named p35SGUS (R. Dolferus, obtained from M. Jacobs, Vrije Universiteit Brussel, Belgium) and pROB5 [5]. p35SGUS is a $5832 \mathrm{bp}$ modified pGEM-3Z vector (Promega) obtained by insertion of a gus gene construct [21] at the EcoR I and Sal I restriction sites.

During Agrobacterium-mediated transformation experiments, disarmed A. tumefaciens strain C58pMP90 [24] transformed with the binary plasmid vector pCAMBIA1301 ([38] obtained from CAMBIA, Camberra, Australia) was used for the cocultivation

Table I. Label and origin of ESM lines subjected to transformation experiments.

\begin{tabular}{lccc}
\hline $\begin{array}{l}\text { ESM } \\
\text { line }\end{array}$ & $\begin{array}{c}\text { Initiation } \\
\text { year }^{\mathrm{a}}\end{array}$ & $\begin{array}{c}\text { Seed } \\
\text { orchard }\end{array}$ & Cross $^{\mathrm{b}^{2}}$ \\
\hline PN519 & 1999 & Le Porge & $4304 \times 4301$ \\
E & 1998 & Sivaillan & $0056 \times 3814$ \\
F311 & 1997 & Sivaillan & $4304 \times 3814$ \\
C115 & 1995 & Sivaillan & $0022 \times 0041$ \\
A104 & 1995 & Vaquey & 1463.104 \\
S100 & 1995 & Vaquey & 2844.100 \\
$1463-13$ & 1993 & Vaquey & $1463 . X$ \\
$1463-15$ & 1993 & Vaquey & $1463 . X$ \\
\hline
\end{tabular}

"All lines were initiated from immature zygotic embryos as described in Bercetche and Pâques [3].

${ }^{b}$ Full-sib cross (mother clone $\times$ father clone), half-sib cross (mother clone followed by label of pollen bulk lot from selected father clones), or open pollination (X) of mother clones. 
experiments. C58pMP90 was kindly provided by L. Jouanin (INRA Versailles, France). Within pCAMBIA1301, the gus gene is interrupted with a catalase intron for suppressed activity in prokaryotes [38]. Proximal to the right border of transfer DNA (T-DNA), gus is in inverse orientation compared to $h p t$ gene located close to the left border. In all vectors, gus and hpt genes are under the control of constitutive CaMV35S promoter [32].

\subsection{Transformation procedures}

All transformation experiments were carried out 3-7 days after subculture, i.e. during the phase of active ESM growth on semi-solid medium.

For microprojectile bombardment (ESM lines 1463-13 and 1463-15), the protocol developed by Bercetche et al. [4] for Picea abies was adapted. Tungstene particles $(1.2 \mu \mathrm{m})$ were coated with an equimolar mixture of plasmids p35SGUS and pROB5 using the procedure of Klein et al. [22]. Prior to transformation, ESM were suspended in liquid proliferation medium $\left(200 \mathrm{mg} \mathrm{mL}^{-1}\right.$ fresh weight) and spread onto a sterile nitrocellulose filter $(5 \mu \mathrm{m}$ pore size) at a cell density of about $50 \mathrm{mg} \mathrm{cm}^{-2}$. Filters were placed on solid proliferation medium in a Petri dish and bombarded $(0.4 \mu \mathrm{g}$ plasmid mixture/filter) using an affordable home-made particle gun device described by Lambe et al. [27]. The microcarrier travel distance was $7 \mathrm{~cm}$ and the vacuum pressure in chamber was equivalent to about $30 \mathrm{~mm} \mathrm{Hg}$. Seven days after bombardment, cells were applied to new filters in order to reach a cell density of about $15 \mathrm{mg} \mathrm{cm}^{-2}$ and transferred every ten days on the same medium containing $10 \mathrm{mg} \mathrm{L}^{-1}$ (line 1463-15) or $20 \mathrm{mg} \mathrm{L}^{-1}$ (line 1463-13) hygromycin $\mathrm{B}$ as a selective agent of transformed cells.

For Agrobacterium-mediated transformation (ESM lines PN519, F311, E, C115, A104, and S100), a modification of the protocol by Levée et al. [30] was evaluated. ESM were rapidly and meticulously suspended in their proliferation medium $\left(200 \mathrm{mg} \mathrm{mL}^{-1}\right.$ fresh weight) using brief pulses (1-2 s) at $2500 \mathrm{rpm}$. A. tumefaciens C58pMP90 strain was grown at $28^{\circ} \mathrm{C}(300 \mathrm{rpm})$ in liquid LB medium (Miller's modification, Sigma) containing $50 \mathrm{mg} \mathrm{L}^{-1}$ rifampicin (chromosomal selection), $20 \mathrm{mg} \mathrm{L}^{-1}$ gentamycin (plasmid Ti selection), and $20 \mathrm{mg} \mathrm{L}^{-1}$ kanamycin (pCAMBIA1301 selection). After 10-12 h proliferation from a reactivated glycerol stock (overnight pre-culture) to an optical density at $600 \mathrm{~nm}\left(\mathrm{OD}_{600}\right)$ of 0.5 to 0.75 (ca. $6-8 \times 10^{8}$ viable bacteria per $\mathrm{mL}$ ), Agrobacterium culture (one volume equal to ESM suspension) was centrifuged and re-suspended in the same volume of plant proliferation medium containing $200 \mu \mathrm{M}$ acetosyringone. Plant cells and agrobacteria were finally mixed and the resulting suspension $\left(3-4 \times 10^{8}\right.$ viable bacteria per $100 \mathrm{mg}$ ESM per $\mathrm{mL}, 100 \mu \mathrm{M}$ acetosyringone) was spread on Whatman filter paper No. 2 (55 mm diameter) at a cell density of $30 \mathrm{mg} \mathrm{cm}^{-2}$ (5 ml per filter) using a low-pressure pulse on a Buchner funnel. Cocultivation of plant cells and Agrobacterium in a Petri dish containing $25 \mathrm{~mL}$ plant proliferation medium with $100 \mu \mathrm{M}$ acetosyringone was performed for 2 days. Filters were then placed on a Buchner funnel and simply washed by gravity with proliferation medium $(100 \mathrm{~mL})$ followed by a brief low-pressure pulse. To remove bacteria, each filter was incubated for $20 \mathrm{~min}$ in a Petri dish containing $25 \mathrm{~mL}$ proliferation medium supplemented with $300 \mathrm{mg} \mathrm{L}^{-1}$ Augmentin $^{\mathrm{TM}}$ (decontamination medium) and subsequently washed with proliferation medium $(200 \mathrm{~mL})$ as described above. After the last wash, filters were placed for one week onto solidified decontamination medium and for one additional week onto the same medium supplemented with $20 \mathrm{mg} \mathrm{L}^{-1}$ hygromycin (selective medium). At this stage, filters were discarded and cells were arranged in small aggregates of about $50 \mathrm{mg}$ (15-20 per Petri dish) weekly transferred onto fresh medium to promote proliferation of hygromycin-resistant lines. Augmentin ${ }^{\mathrm{TM}}$ could be removed after only 4-5 weeks selection and Agrobacterium regrowth could not be subsequently detected. Putative transformed lines were collected each week on the small cell aggregates and invariably proliferated on selective medium (i.e. with hygromycin B). Hygromycin-resistant lines were numbered after 20 weeks selection.

\subsection{Transgene expression}

Histochemical GUS assays of ESM lines, somatic embryos and somatic plant organs (radicle apices, needles) were performed according to Stomp [41] and inspected either by eye or under microscope $\left(5 \times\right.$ magnification) after $4-12 \mathrm{~h}$ incubation at $37^{\circ} \mathrm{C}$ (blue colour development). The reaction buffer ( $\mathrm{pH}$ 8.0) is designed for specific elimination of endogenous $\beta$-glucuronidase activity in transgenic and non-transgenic tissues and plants [19].

\subsection{Transgene detection}

For molecular detection of gus and hpt genes by polymerase chain reaction (PCR), genomic DNA was extracted and purified from $150 \mathrm{mg}$ ESM, plant needles or roots using the DNeasy plant mini kit (Qiagen) following the manufacturer's instructions. Three combinations of primers were used to amplify:

(1) a 1026 bp gus gene region [17],

Forward primer:

5'-GCC ATT TGA AGC CGA TGT CAC GCC-3'

Reverse primer:

5'-GTA TCG GTG TGA GCG TCG CAG AAC-3'

(2) a 412 bp hpt gene region [33],

Forward primer:

5'-AAC CAC GGC CTC CAG AAG AAG ATG-3'

Reverse primer:

\section{5'-ACC TGC CTG AAA CCG AAC TGC CCG-3'}

(3) a 561 bp virD gene region located on the Agrobacterium plasmid $\mathrm{Ti}(\mathrm{pTi})$ to check for any contamination of putatively transformed ESM lines and plants (J. Velten, USDA-ARS, Lubbock, USA).

Forward primer: 5'-GAA GAA AGC CGA AAT AAA GAG-3'

Reverse primer: 5'-TTG AAC GTA TAG TCG CCG ATA-3'

All reactions were performed in a $25 \mu \mathrm{L}$ volume on a PTC-100 thermal cycler (MJ Research). Samples containing $50 \mathrm{ng}$ genomic DNA, $2 \mathrm{mM} \mathrm{MgCl}, 0.2 \mathrm{mM}$ of each dNTP, $0.2 \mu \mathrm{M}$ of each primer and $25 \mathrm{U} \mathrm{mL}^{-1}$ Taq DNA polymerase recombinant (Gibco BRL) were first heated at $96{ }^{\circ} \mathrm{C}$ for 5 min followed by 35 cycles of $94{ }^{\circ} \mathrm{C}$ for $1 \mathrm{~min}, 61^{\circ} \mathrm{C}$ (gus, virD) or $62{ }^{\circ} \mathrm{C}(h p t)$ for $1 \mathrm{~min}$, and $72{ }^{\circ} \mathrm{C}$ for $2 \mathrm{~min}$. A final extension step of $10 \mathrm{~min}$ at $72{ }^{\circ} \mathrm{C}$ followed by cooling to $4{ }^{\circ} \mathrm{C}$ was performed. PCR products were separated on $1.5 \%$ agarose gels and visualized by ethidium bromide staining.

For Southern blot experiment, genomic DNA was extracted and purified from ESM or plant needles using the DNeasy plant maxi kit (Qiagen) following the manufacturer's instructions. Genomic DNA was subsequently concentrated by ethanol precipitation. Purified DNA (approximately $15 \mu \mathrm{g}$ ) was digested with excess $\left(3 \mathrm{U}^{-1}\right)$ of endonucleases (MBI Fermentas, see figure 6), separated by electrophoresis (overnight) on a $0.7 \%$ agarose gel $\left(1 \mathrm{~V} \mathrm{~cm}^{-1}\right)$, blotted onto Hybond $\mathrm{N}+$ nylon membrane (Amersham), and hybridised using ${ }^{32} \mathrm{P}$ labelled, random-primed, gel-purified (prep-a-gene, Biorad) PCR fragments (primers as described in PCR analysis) of the gus (1026 bp) and hpt (412 bp) genes as probes. Hybridisation and autoradiography were carried out according to standard methodology [39]. 


\section{RESULTS}

\subsection{Transformation efficiency}

ESM lines subjected to transformation experiments ( $t a-$ ble I) did not grow on medium containing hygromycin $\mathrm{B}$ at concentrations of $20 \mathrm{mg} \mathrm{L}^{-1}$ or higher (figure 1). After 5 weeks subculture on selective medium, the initial fresh weight indeed dramatically decreased owing to loss of water commonly observed when ESM are placed on media containing antibiotics [47]. The toxic effect of hygromycin could be clearly detected as early as 7 days after transfer of ESM on selective medium (data not shown). Hygromycin at $10 \mathrm{mg} \mathrm{L}^{-1}$ was found to be sufficient to inhibit growth of ESM line 1463-15 but $20 \mathrm{mg} \mathrm{L}^{-1}$ was required for genotype $1463-13$. Hygromycin B at $20 \mathrm{mg} \mathrm{L}^{-1}$ could finally be proposed as the optimal selective conditions of transformed cells for most ESM genotypes.

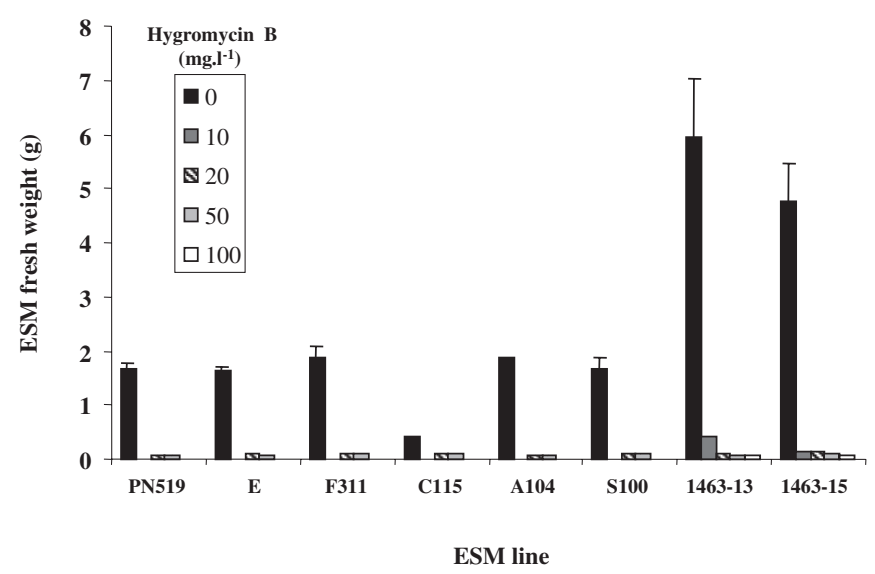

Figure 1. Evaluation of optimal hygromycin B concentration for selection of transgenic tissue from 8 ESM lines - ESM fresh weight $(\mathrm{g})$ was determined after 5 weeks subculture on selective medium with different concentrations of hygromycin B. Values are the average of 3-4 replicates (bar $=$ standard error). Initial ESM fresh weight was $0.200 \mathrm{~g}$.

Table II. Transformation efficiency of 2 ESM lines in separate experiments using particle bombardment (FW: fresh weight; SE: standard error).

\begin{tabular}{lccccc}
\hline \multirow{2}{*}{$\begin{array}{l}\text { ESM } \\
\text { line }\end{array}$} & Experiment & ESM & \multicolumn{3}{c}{ Number of hygromycin-resistant lines } \\
\cline { 4 - 6 } $1463-15$ & label & FW (g) & Total & Total/g FW & Mean/g FW \pm SE \\
& 1 & 8.0 & 131 & 16.37 & $11.49 \pm 4.70$ \\
& 2 & 4.0 & 64 & 16.00 & \\
& 3 & 4.8 & 10 & 2.08 & \\
$1463-13$ & Total & 16.8 & 205 & 12.20 & \\
\hline
\end{tabular}

One to four independent transformation experiments ( 2 to $10 \mathrm{~g}$ ESM fresh weight) were performed for either two ESM lines (genotypes 1463-13 and 1463-15) using particle bombardment, or 6 ESM lines (genotypes PN519, F311, E, C115, A104, and S100) using Agrobacterium-mediated DNA transfer.

The biolistic method yielded stable hygromycin-resistant lines in all 4 experiments (table II) within 4-17 weeks selection. Up to 15 (genotype 1463-13) or 16 (genotype 1463-15) hygromycin-resistant lines were obtained per gram fresh weight of bombarded ESM. Considering 1463-15, an overall mean of 11.5 hygromycin-resistant lines/g could be obtained over 3 independent experiments.

Stable hygromycin-resistant lines were similarly recovered within 4-19 weeks selection (maximum after 8-11 weeks) after Agrobacterium-mediated transformation but results were contrasted, depending on ESM line and experiment (table III). One genotype (PN519) was apparently highly receptive and produced 44 to 135 hygromycin-resistant lines/g (overall mean: 88.3 lines/g). Genotype E gave results of the same magnitude to that obtained for genotype 1463-15 during biolistic with up to 14 hygromycin-resistant lines/g. However, it should be noted that during one experiment this genotype could not be transformed (overall mean: 7.4 lines/g). Similarly, genotypes A104 and S100 only sporadically produced stable hygromycin-resistant lines (only

Table III. Transformation efficiency of 6 ESM lines in separate experiments using Agrobacterium-mediated DNA transfer (FW: fresh weight; SE: standard error).

\begin{tabular}{lccccc}
\hline \multirow{2}{*}{ ESM } & Experiment & ESM & \multicolumn{3}{c}{ Number of hygromycin-resistant lines } \\
\cline { 5 - 6 } line* & label & FW $(\mathrm{g})$ & Total & Total/g FW & Mean/g FW \pm SE \\
\hline PN519 & 1 & 2.5 & 338 & 135.20 & $88.29 \pm 19.06$ \\
& 2 & 2.5 & 243 & 97.20 & \\
& 3 & 10.0 & 765 & 76.50 & \\
& 4 & 4.0 & 177 & 44.25 & \\
E & Total & 19.0 & 1523 & 80.16 & \\
& 1 & 2.0 & 29 & 14.50 & $7.39 \pm 4.19$ \\
& 2 & 3.0 & 23 & 7.67 & \\
& 3 & 4.0 & 0 & 0 & \\
A104 & Total & 9.0 & 52 & 5.78 & \\
& 1 & 9.0 & 1 & 0.11 & $0.03 \pm 0.03$ \\
& 2 & 3.0 & 0 & 0 & \\
& 3 & 3.0 & 0 & 0 & \\
& 4 & 4.0 & 0 & 0 & \\
S100 & 1 & 4.0 & 1 & 0.25 & $0.08 \pm 0.08$ \\
& 2 & 3.0 & 0 & 0 & \\
& 3 & 3.0 & 0 & 0 & \\
& Total & 19.0 & 1 & 0.05 & \\
& 1 & 10.0 & 1 & 0.10 &
\end{tabular}

* Lines C115 and F311 could not be transformed (3 independent experiments). 


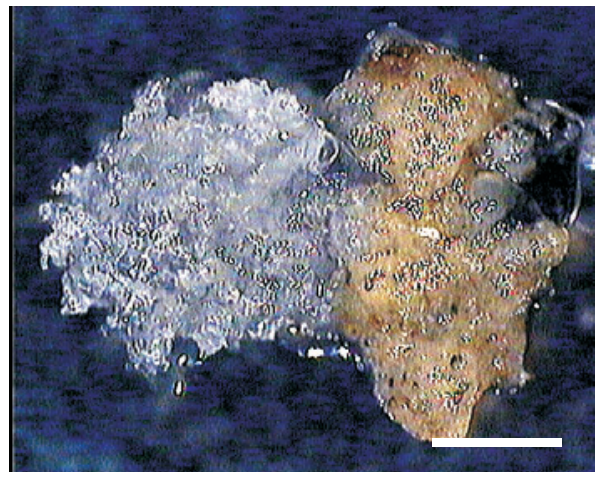

A

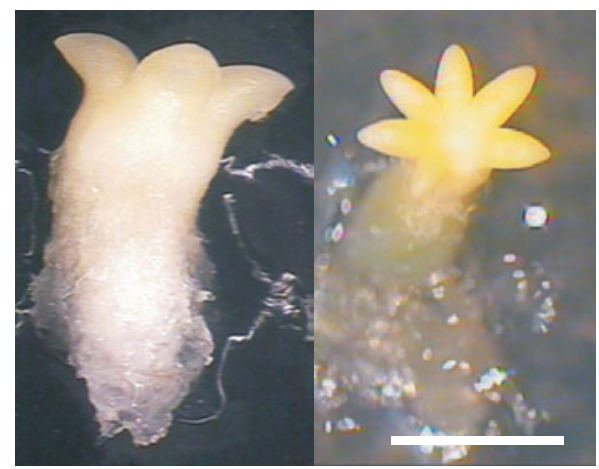

B

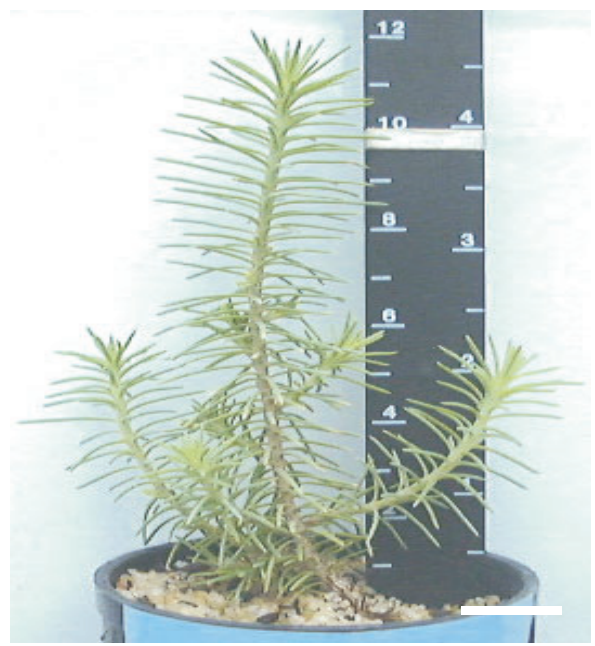

C

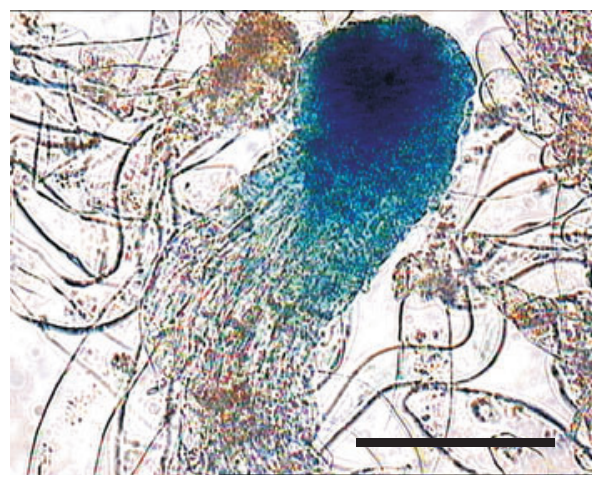

D
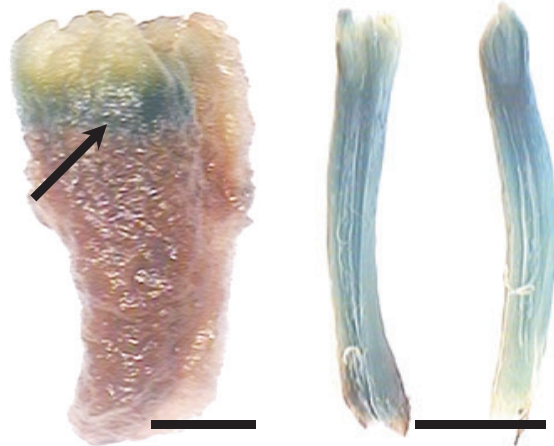

$\mathbf{E}$

$\mathbf{F}$

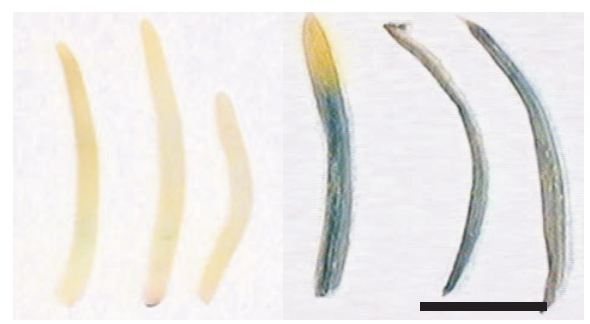

G

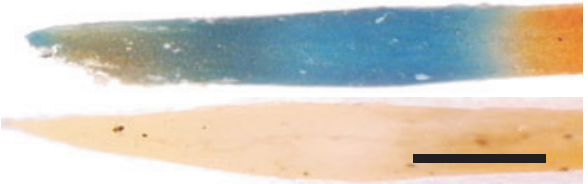

$\mathbf{H}$

Figure 2. Plantlet recovery from hygromycin-resistant lines expressing gus produced either by the biolistic or Agrobacterium procedures. Time course (A-C) and corresponding histochemical GUS assays (D-H).

A. Hygromycin-resistant cells (white and translucent) growing at the surface of small inhibited cell aggregates (brown). Bar $=1 \mathrm{~mm}$. B. White (left) and yellow (right) appearance of cotyledonary somatic embryos after 3 months maturation. Bar $=1 \mathrm{~mm}$. C. Transgenic plantlet ( 3 months old). Bar $=2 \mathrm{~cm}$. D. Immature somatic embryo expressing gus. Bar $=100 \mu \mathrm{M}$. E. Mature somatic embryo expressing gus at the level of the young cotyledons ring (arrow). Bar $=0.5 \mathrm{~mm}$. F. Longitudinal section of elongating somatic embryo expressing gus. Bar $=1 \mathrm{~mm}$. G. gus expression in young needles (right) compared to non-transformed controls (left). Bar $=5 \mathrm{~mm}$. H. gus expression in radicle apices (up) compared to non-transformed control (down). Bar $=1 \mathrm{~mm}$. 
one line obtained, i.e. less than one line per gram ESM) and we were unable to recover stable hygromycin-resistant lines from genotypes $\mathrm{C} 115$ and F311. In the case of C115, agrobacteria re-growth was invariably observed in all experiments using prolonged decontamination step following cocultivation (up to $40 \mathrm{~min}$ ), not only with Augmentin ${ }^{\mathrm{TM}}$ (300 $\left.\mathrm{mg} \mathrm{L}^{-1}\right)$, but also with carbenicilline $\left(500 \mathrm{mg} \mathrm{L}^{-1}\right)$ and cefotaxime $\left(250 \mathrm{mg} \mathrm{L}^{-1}\right)$. The increase of Augmentin ${ }^{\mathrm{TM}}$ concentration to $600 \mathrm{mg} \mathrm{L}^{-1}$ in the decontamination solid culture medium was equally ineffective.

Bacterial inoculum density $\left(0.2 \mathrm{OD}_{600} 1.1, \mathrm{ca} .10^{8}-10^{9}\right.$ viable bacteria $\left.\mathrm{mL}^{-1}\right)$ and acetosyringone concentration $(0-200 \mu \mathrm{M})$ during the cocultivation step did not appear as important factors to improve transformation efficiency (data not shown). However, sample size may not have been large enough in these experiments to demonstrate a small significant difference.

\subsection{Plantlets recovery from hygromycin-resistant lines}

Using our improved protocols for maturation and germination of somatic embryos in maritime pine $[3,36,37]$ somatic plants were recovered from hygromycin-resistant lines (figure 2) produced either by particle bombardment of genotype 1463-13 or Agrobacterium-mediated DNA transfer to genotype PN519. Selection and stabilisation of hygromycinresistant lines were achieved within one to four months, depending on their growth rate (figure $2 A$ ). At this stage, all transformed materials were cryopreserved using an efficient technique developed by AFOCEL in order to maintain juvenility and maturation ability. When transferred onto our improved maturation media [36] using adapted ESM sampling [37], hygromycin-resistant lines produced cotyledonary somatic embryos within 3 months (figure $2 B$ ). These embryos were able to germinate. Conversion into plantlets grown in the greenhouse needed 4 to 5 additional months (figure 2C). Thus, our protocol of genetic transformation of maritime pine yielded transgenic plants within one year. In the case of cryopreserved lines, 3 more months were required to reactivate the tissue prior to maturation treatments.

\subsection{GUS activity}

After 20 weeks selection, GUS activity was revealed by histochemical assays in $61 \%$ hygromycin-resistant lines recovered from biolistic $(\mathrm{n}=326$ lines tested, genotypes 1463-13 and 1463-15) or 87\% hygromycin-resistant lines obtained during Agrobacterium experiments $(\mathrm{n}=132$ lines tested, genotypes PN519, E, S100 and A104). The large difference observed between the two methods could obviously be attributed to the distinct transformation procedure employed, i.e. gus and $h p t$ on different plasmids p35SGUS and pROB5 (biolistic) or on the same plasmid pCAMBIA1301 (Agrobacterium). Although not quantified, the GUS activity was apparently lower (data not shown) in Agrobacterium- derived lines (detection mainly under microscope) compared to lines obtained by biolistic (detection mainly by eye).

In a random selection of 22 hygromycin-resistant lines recovered from genotype PN519, 15 showed stable expression over time (several months proliferation weekly subcultured), 4 only transient or irregular expression during the early 14-26 weeks selection period, and 3 no expression. The $\beta$-glucuronidase activity remained detectable even after up to 4 years cryopreservation of hygromycin-resistant lines in liquid nitrogen.

Transformation efficiency of different genotypes computed as the number of hygromycin-resistant lines expressing gus per gram ESM subjected to DNA transfer, could finally be ranged from 7.0 to 8.5 using the biolistic method and from 0 to 67.3 using Agrobacterium-mediated DNA transfer (figure 3).

Microscopic observation clearly revealed GUS activity in disseminated or tissue-organised (embryo head) meristematic and suspensor cells (figure 2D). In mature somatic embryos, the histochemical GUS assay was usually positive at the level of the ring of young cotyledons (figure $2 E$ ) or more clearly in longitudinal sections (figure $2 F$ ). Sectioning the embryo prior to GUS assay increased substrate penetration and development of reaction product. Considering acclimatised plants, root apices gave strong blue coloration results for all investigated plants (figure $2 \mathrm{H}$ ). Compared to control non-transformed plants the GUS activity was detected in the meristematic and root cap regions. Young needles were equally reactive (figure $2 G$ ).

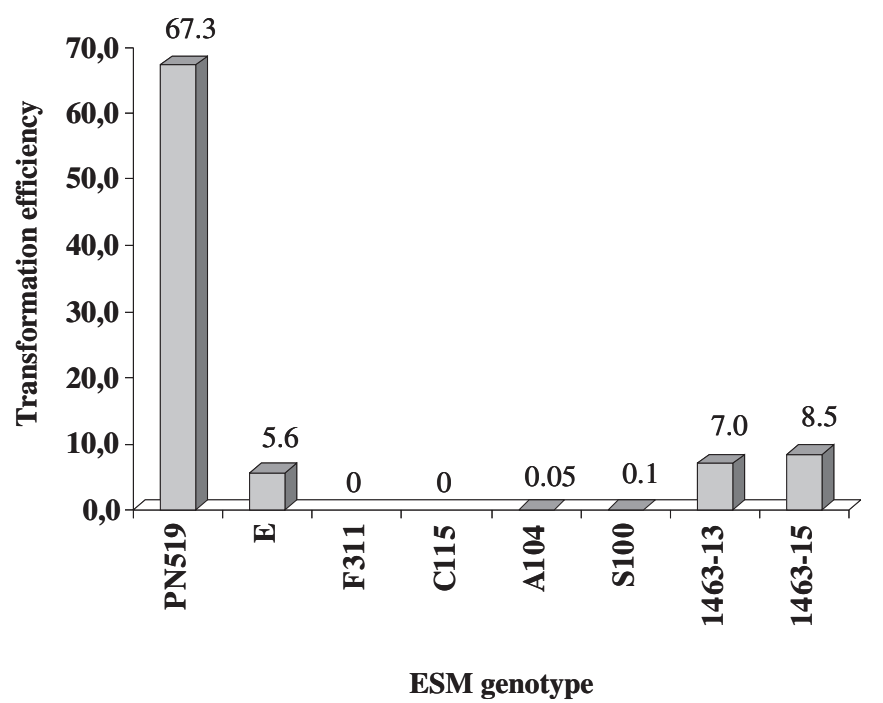

Figure 3. Transformation efficiency of Pinus pinaster genotypes computed as the number of hygromycin-resistant lines expressing gus per gram ESM (fresh weight) subjected to DNA transfer via Agrobacterium tumefaciens (genotypes PN519, E, F311, A104, S100) or particle bombardment (genotypes 1463-13 and 1463-15). 


\subsection{Molecular detection of transgenes}

The transgenic state of hygromycin-resistant lines and plants obtained by the biolistic method could be demonstrated by PCR amplification of a 1026 bp gus gene region and a 412 bp hpt gene region (figure 4). The 412 bp fragment was detected in all investigated lines and plants (figure 4A), thus demonstrating that hygromycin B is an effective selective agent to recover transgenic lines and inhibit growth of non-transformed cells. We concluded that no escape (false positive hygromycin-resistant line) was obtained during our experiments. Considering gus (figure 4B), the 1026 bp gene region was amplified in most lines and plants tested. Only two hygromycin-resistant lines, confirmed as GUS negative by histochemical assays, did not yield the expected fragment (lanes 10 and 12).

Similar results were obtained for a selection of hygromycin-resistant lines obtained from Agrobacterium experiments (figure 5). No escape was detected (figure 5A). As gus gene was located near the right border of T-DNA, first transferred in the genome, it was found to be integrated in most hygromycin-resistant lines tested (figure 5B), including some lines that did not express gus at a detectable level (lanes $\mathrm{g}$ and $\mathrm{h}$ ). In the case of lane $\mathrm{j}$, a very faint amplification signal is visible and we confirmed PCR amplification of the gus gene during other experiments (data not shown). As expected, one line confirmed as GUS negative by histochemical assay did not produce the $1026 \mathrm{bp}$ fragment (lane i). We concluded that irregular and/or repression of gus expression (silencing) only occurred in a few cases.

No evidence of Agrobacterium re-growth could be revealed in transformed lines weekly subcultured for several months without any antibiotic. PCR assays based on the amplification of a $561 \mathrm{bp}$ fragment from the virulence gene $\operatorname{vir} \mathrm{D}$ that codes for a protein involved in transport of T-DNA into the plant cell nucleus and in T-DNA integration [25] did not yield the expected fragment (figure 5C). Only faint bands of slightly different size (517 and $580 \mathrm{bp}$ ) could be observed in some lanes $(\mathrm{a}, \mathrm{c}, \mathrm{d}, \mathrm{j}, \mathrm{l}, \mathrm{n})$ and were interpreted as non-specific amplification of genomic DNA because they were invariably detected in the control, non-transformed DNA. Moreover, the GUS activity detected in these lines is in total accordance with genetic transformation owing to the presence of the catalase intron, which inhibited gus expression in bacteria.

To confirm the integration of transgenes, one hygromycin-resistant line expressing gus (X15, see lane 13 in figure 4) obtained from ESM line 1463-13 and one
Hygromycin-resistant lines

A

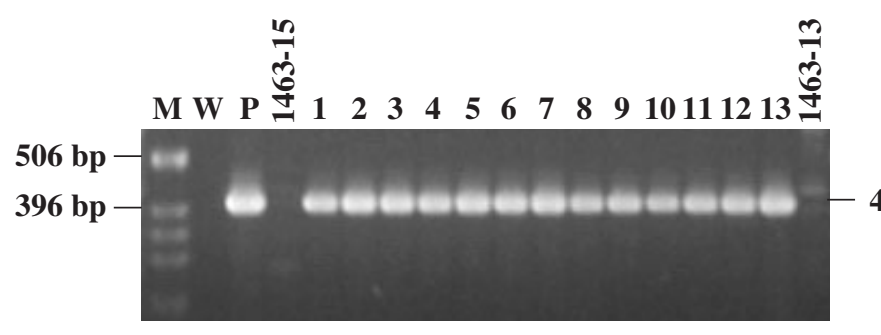

B

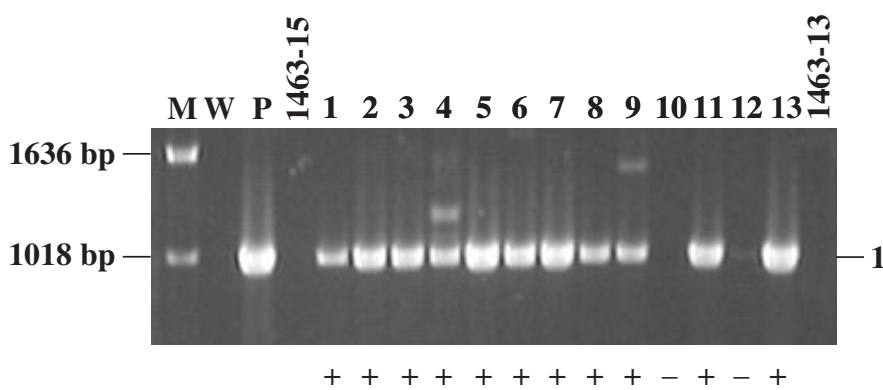

$412 \mathrm{bp}$

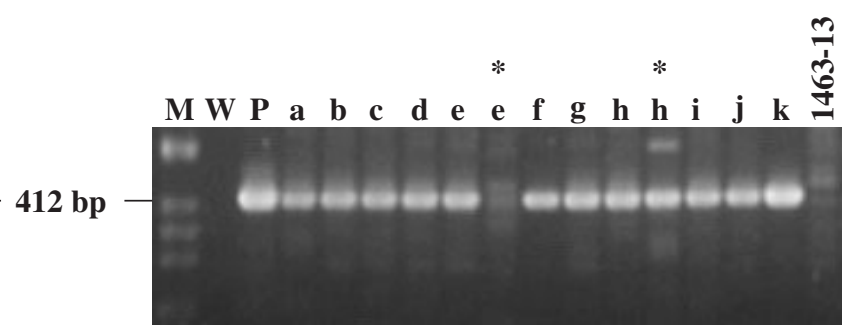

\section{Somatic plants}

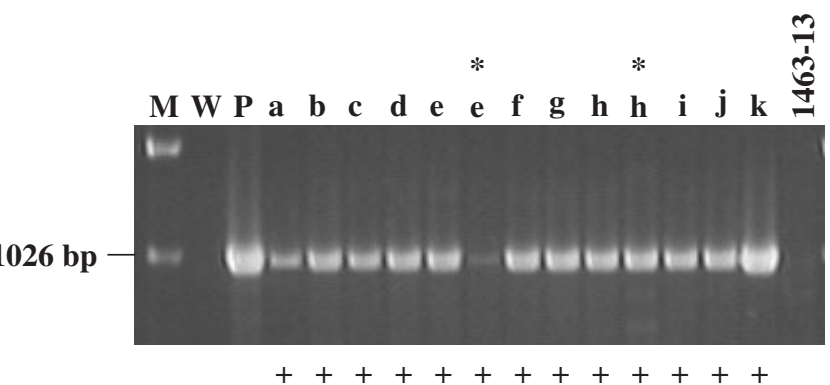

Figure 4. PCR analysis of hygromycin-resistant lines (lanes 1-13) and derived somatic plants (lanes a-k) obtained by particle bombardment. A. Detection of a $412 \mathrm{bp} \mathrm{hpt} \mathrm{gene} \mathrm{region.} \mathrm{B.} \mathrm{Detection} \mathrm{of} \mathrm{a} 1026 \mathrm{bp}$ gus gene region. +/- is referring to results obtained for GUS histochemical assays of hygromycin-resistant lines, needles or roots (positive/negative).

M: $1 \mathrm{~Kb}$ DNA ladder (Gibco BRL); W: water control (no DNA); P: plasmid positive control (100 pg p35SGUS or pROB5); 1463-13 and 1463-15: non-transformed ESM lines; lanes 1-3: hygromycin-resistant lines obtained from genotype 1463-15; lanes 4-13: hygromycin-resistant lines obtained from genotype 1463-13; lanes a-k: somatic plants obtained from hygromycin-resistant lines produced by genotype $1463-13$. The asterisk $(*)$ indicates that genomic DNA was extracted from roots instead of needles. 
A

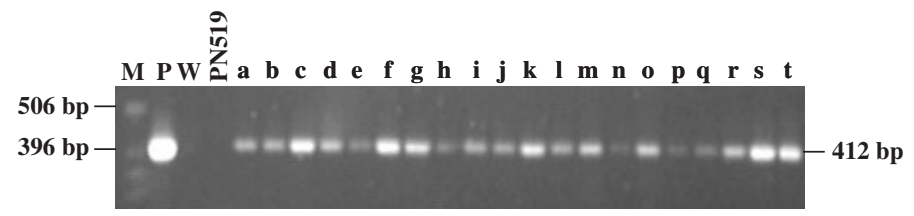

B

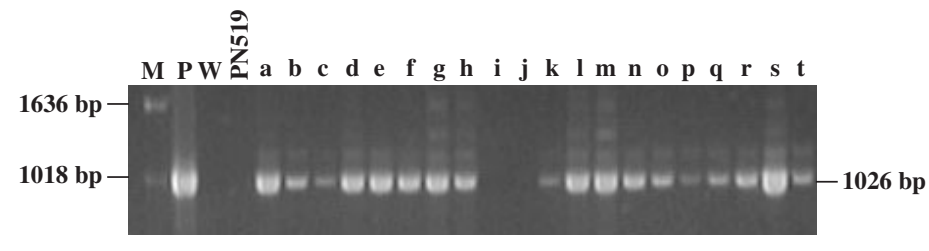

C

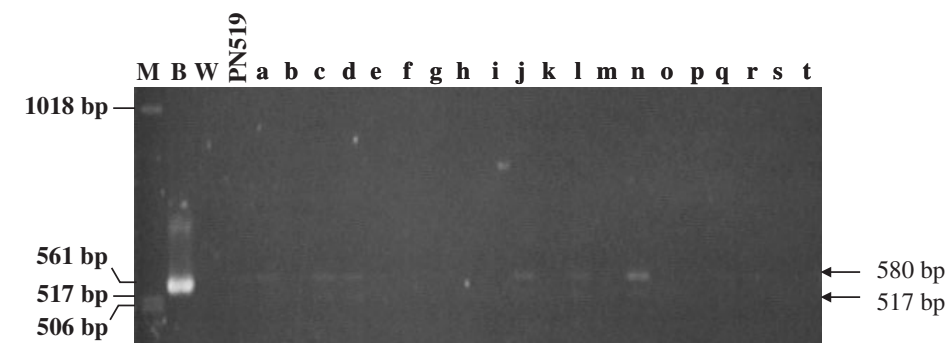

Figure 5. PCR analysis of hygromycin-resistant lines (lanes a-t) obtained by cocultivation of PN519 ESM with A. tumefaciens C58pMP90. A. Detection of a 412 bp hpt gene region. B. Detection of a 1026 bp gus gene region. $+/-$ is referring to results obtained for GUS histochemical assays (positive/negative). C. Detection of a 561 bp virD gene region located on A. tumefaciens pTi.

M: $1 \mathrm{~Kb}$ DNA ladder (Gibco BRL); W: water control (no DNA); P: plasmid positive control (100 pg pCAMBIA1301); B: bacterial positive control (C58pMP90 colonies picked up); PN519: non-transformed ESM lines. The faint bands of about $580 \mathrm{bp}$ and $517 \mathrm{bp}$ indicated by the 2 arrows are non-specific PCR products (also detected in the non-transformed line PN519).

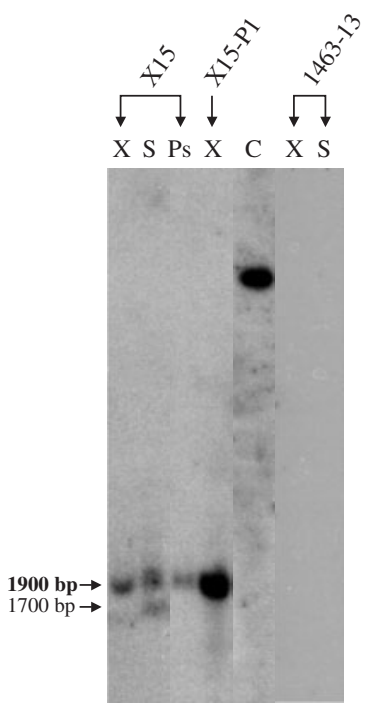

gus probe

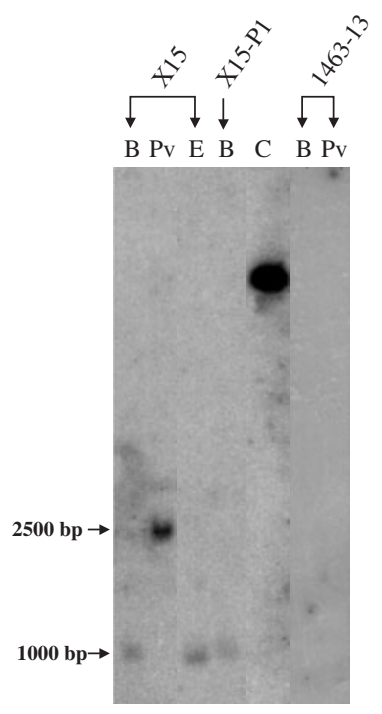

hpt probe
Figure 6. Southern blot of genomic DNA from the transformed line X15 and derived somatic plant X15-P1 obtained after microprojectile bombardment of ESM line 1463-13 with plasmids p35SGUS and pROB5. A total of $15 \mu \mathrm{g}$ of genomic DNA extracted from ESM or plant needles was digested with endonucleases and hybridised with ${ }^{32} \mathrm{P}$-labelled gus or $h p t$ probes.

C: positive control DNA (2 ng of linearised plasmid vector with gus or hpt genes). 1463-13: control non-transformed genomic DNA extracted from needles of somatic plant derived from ESM line 1463-13.

X: Xba I; S: Sal I; Ps: Pst I; B: BamH I; Pv: Pvu II; E: EcoR I. Fragments of predicted size are shown by arrows. derived somatic plant (X15-P1, see lane $\mathrm{k}$ in figure 4) were analysed by Southern hybridisation (figure 6). No bands were detected in the non-transgenic control (1463-13) using either gus or $h p t$ probes whereas bands of predicted size for gus (approximately 1900 bp with Xba I, Sal I and Pst I) and hpt (approximately $1000 \mathrm{bp}$ with BamH I and EcoR I; approximately $2500 \mathrm{bp}$ with $P v u \mathrm{II}$ ) were observed (arrows) in the transgenic line X15 and plant X15-P1 confirming the presence of foreign genes integrated into the Pinus pinaster genome. The additional, unpredicted fragment of approximately 1700 bp observed with Sal I could be due to incomplete or non-specific digestion.

\section{DISCUSSION}

Stable genetic transformation and regeneration of selected Pinus pinaster genotypes with selective hpt and reporter gus genes could be achieved within 1 year by two different approaches commonly used for plant transformation, i.e. the biolistic and Agrobacterium-mediated procedures. To date, only Picea abies was reported to be genetically modified using both methods [48, 49]. In the family Pinaceae, the main group of gymnosperms subjected to transformation attempt [2], pine seemed generally more difficult to transform than spruce [16, 43, 48] or larch (reviewed in [35]). Transient expression could be obtained in $P$. taeda, $P$. banksiana, $P$. contorta, $P$. sylvestris and $P$. palustris $[12,30,49]$, but only two recent studies reported on stable transformation of ESM with regeneration of transgenic plants, i.e. in P. strobus 
via Agrobacterium tumefaciens [30] and Pinus radiata using biolistic $[6,47]$.

Using our affordable biolistic method, we obtained in Pinus pinaster comparable results (7.0-8.5 transformed lines/g ESM, 2 genotypes) to that reported by Walter et al. [47] for Pinus radiata (0-20.0 transformed lines/g ESM, 4 genotypes). Clearly, more Pinus pinaster genotypes should be tested to estimate if our biolistic method is genotype-dependent in Pinus pinaster as it seems to be the case for Pinus radiata.

Our modification of the procedure of Levée et al. [30] using the C58pMP90 Agrobacterium strain yielded similar or higher results in Pinus pinaster (0-67.3 transformed line expressing gus/g ESM, 6 genotypes) compared to Pinus strobus (4.0 transformed lines/g ESM, 1 genotype). Interestingly, the C58pMP90 Agrobacterium strain was also revealed to be advantageous for Picea abies transformation [49]. However, Agrobacterium-mediated DNA transfer in Pinus pinaster was apparently highly dependent on genotype, physiological receptivity of ESM and bacterial decontamination step following cocultivation. Genotype F311 was indeed definitely recalcitrant, genotypes A104 and S100 were poorly receptive, whereas genotype PN519 was efficiently transformed and can obviously serve as a model for further optimisation. In the case of genotype E, some experiments failed to produce hygromycin-resistant lines, suggesting that ESM were not in a continual receptive physiological state over time for DNA transfer (e.g. decreased vigour, ageing during subculture, etc.). Residual bacteria consistently observed in C115 after decontamination using 3 recommended antibiotics was interpreted as a genotype-related protection effect possibly involving excreted plant cell compounds such as mucilages.

It should be noted that among the 6 unrelated genotypes tested (table I), 4 could be transformed (PN519, E, A104 and S100). Similar conclusions were obtained during Agrobacterium-mediated transformation of hybrid larch ESM with 4 out of 7 genotypes transformed with very contrasted efficiencies [29]. Such results suggested that our Agrobacterium procedure may be applicable to a wide range of selected genotypes after identification of main variation sources (e.g. bacterial strain, T-DNA construct, ESM ageing, post co-cultivation step, etc.). The amount of Agrobacterium was not an important factor for improved transformation efficiency in maritime pine. Similar results were obtained in Pinus strobus [30], but Wenck et al. [49] found that less than $10^{8}$ bacteria were ineffective at transformation of Picea abies. The bacterial inoculum range tested in our study $\left(10^{8}-10^{9}\right.$ viable bacteria $\mathrm{mL}^{-1}$ ) is thus apparently appropriate. Considering acetosyringone concentration in the cocultivation, up to $200 \mu \mathrm{M}$ did not lead to an increase in transformation yields. In contrast, transformation was found to be influenced by the presence of this plant elicitor in Picea abies and Pinus taeda (25-50 $\mu \mathrm{M},[49])$, Pinus strobus $(100 \mu \mathrm{M},[30])$ and hybrid larch $(100 \mu \mathrm{M},[29])$.
Based on the combined evidence of GUS activity (figure 2), PCR data (figures 4 and 5), and the prolonged survival of the tissue on selective media (about one year), hygromycin $\mathrm{B}$ was revealed to be a very effective selective agent of transformed cells in Pinus pinaster. At relatively low concentrations $\left(20 \mathrm{mg} \mathrm{L}^{-1}\right)$ transformed cell lines retained their embryogenic potential to produce somatic embryos and plants (figure 2) whereas the growth of control cells was inhibited within only 1 week (see figure 1 and corresponding text). This is $2-3$ weeks earlier compared to kanamycin selection used by Levée et al. [30] and Wenck et al. [49]. As previously reported for Pinus radiata [46] and many crop species [33] using similar hygromycin concentrations (about $25 \mathrm{mg} \mathrm{L}^{-1}$ ), the selection procedure is very reliable since no escape was detected during the selection. The large number of escapes (75-98\%) produced in the case of Picea mariana [43] is probably related with the sublethal hygromycin level (less than $1 \mathrm{mg} \mathrm{L}^{-1}$ ) used in their experiments. Moreover, Wenck et al. [49] could obtain good results in Picea abies with only $2.5 \mathrm{mg} \mathrm{L}^{-1}$ hygromycin in the selective medium. In contrast, the commonly used selection of transformed cells by kanamycin (nptII gene) could yield up to $90 \%$ escapes [9, $16,23]$.

Compared to transformed lines obtained by biolistic, GUS activity after 20 weeks selection was apparently depleted in most Agrobacterium-derived lines. Instead of significant differences in copy number of transgenes between the two methods, this may be related to the low activity of the gus-intron construct as already observed in some species such as Pinus strobus [30], Larix x eurolepis and Picea mariana [13]. As a consequence, we cannot exclude that the GUS activity was too low for histochemical detection in some GUS negative Agrobacterium-derived lines, thus underestimating transformation efficiency (0-67.3 lines/g FW, figure 3). In such an hypothesis, it would be more correct to consider transformation yields based on the number of hygromycin-resistant lines (0-88.3 lines/g FW, table III).

Diagnostic PCR analyses of gus and hpt gene regions were positive for most hygromycin-resistant lines and plants obtained by biolistic (figure 4) or via Agrobacterium (figure 5). In the latter case, no amplification signal of the expected size could be detected with the virD primers (figure 5) inferring that hygromycin-resistant lines were probably free of agrobacteria. Even in the hypothesis of putative Agrobacterium contamination, we concluded that only trace level of bacteria remained in these lines (see the high intensity of virD amplification in the positive bacterial control). At least, the transgenic state of hygromycin-resistant lines expressing gus could be certified owing to the use of the gus-intron construct and absence of bacteria re-growth on medium without any antibiotics. Moreover, introduction of Southern blot analysis confirmed the integration of both transgenes in one hygromycin-resistant ESM line and derived plant produced after microprojectile bombardment. Similar preliminary results were obtained using 
hygromycin-resistant lines obtained via Agrobacterium tumefaciens (data not shown).

Both biolistic or Agrobacterium-mediated DNA procedures can result in integration of multiple disseminated or tandemly arranged copies of the transgene (hotspot) in the host genome [26, 47]. Such an invasive delivery can abolish transgene expression or can cause the deletion of the transgenes. Therefore, further transgene integration analyses at both qualitative and quantitative levels are required to compare and validate the best transformation procedure and envision genetic engineering of maritime pine with genes of interest.

\section{REFERENCES}

[1] Aitken-Christie J., Somatic embryogenesis for large-scale clonal testing and propagation of elite material, in: Abstracts of the WBB Conference, Bordeaux, France, June 11-14, 2001, p. 9.

[2] Bajaj Y.P.S., Transgenic trees, biotechnology in agriculture and forestry, Vol. 44, Springer-Verlag, Germany, 2000.

[3] Bercetche J., Pâques M., Somatic embryogenesis in maritime pine (Pinus pinaster Ait.), in: Jain S.M., Gupta P.K., Newton R.J. (Eds.), Somatic embryogenesis in woody plants, gymnosperms, Vol. 3, Kluwer Academic Publishers, The Netherlands, 1995, pp. 221-242.

[4] Bercetche J., Dinant M., Coosemans N., Pâques M., Matagne R.F., Particle gun: a new transformation possibility in Picea abies, Annales AFOCEL (1992) 29-48.

[5] Bilang R., Lida S., Peterhans A., Potrykus I., Paskowski J., The 3' terminal region of the hygromycin-B-resistance gene is important for its activity in Escherichia coli and Nicotiana tabacum, Gene 100 (1991) 247-250.

[6] Bishop-Hurley S.L., Zabkiewicz R.J., Grace L., Gardner R.C., Wagner A., Walter C., Conifer genetic engineering: transgenic Pinus radiata (D. Don) and Picea abies (Karst) plants are resistant to the herbicide Buster, Plant Cell Rep. 29 (2001) 235-243.

[7] Butcher T.B., Pinus pinaster and P. radiata tree breeding programs, Winston Churchill Memorial Fellowship, report, 1997.

[8] Chaperon H., Maritime pine reforestation in the Aquitaine, Presses de la Société d'Exploitation de l'Imprimerie Couesnon, Champagne-sur-Seine, 1986.

[9] Charest P.J., Devantier Y., Lachance D., Stable genetic transformation of Picea mariana (black spruce) via particle bombardment, In Vitro Cell. Dev. Biol. Plant 32 (1996) 91-99.

[10] Clapham D., Demel P., Elfstrand M., Koop H.U., Sabala I., Von Arnold S., Gene transfer by particle bombardment to embryogenic cultures of Picea abies and the production of transgenic plantlets, Scand. J. For. Res. 15 (2000) 151-160.

[11] Cyr D., Cryopreservation of embryogenic cultures of conifers and its application to clonal forestry, in: Jain S., Gupta P., Newton R. (Eds.), Somatic embryogenesis of woody plants, Kluwer, Dordrecht, The Netherland, 1999, Vol. 4, pp. 239-262.

[12] Diner A.M., Genetic transformation of Pinus palustris (Longleaf Pine), in: Bajaj Y.P.S. (Ed.), Biotechnology in agriculture and forestry, Vol. 44, Transgenic trees, Sringer-Verlag, Germany, 2000, pp. 185-191.

[13] Duchesne L.C., Charest P.J., Effect of promoter sequence on transient expression of the $\beta$-glucuronidase gene in embryogenic calli of Larix x eurolepsis and Picea mariana following microprojection, Can. J. Bot. 70 (1992) $175-180$.

[14] Dumas E., Monteuuis O., In vitro regeneration of old maritime pines using adventitious budding from euphylls, Annales AFOCEL (1990) 44-56.

[15] Dumas E., Franclet A., Monteuuis O., Apical meristem micrografting of mature maritime pines (Pinus pinaster Ait.) onto in vitro young seedlings, C. R. Acad. Sci. Paris (III) 309 (1989) 723-728.
[16] Ellis D.D., McCabe D.E., McInnis S., Ramachandran R., Russell D.R., Wallace K.M., Martinell B.J., Roberts D.R., Raffa K.F., McCown B.H., Stable transformation of Picea glauca by particle acceleration, Biotechnology 11 (1993) 84-89.

[17] Enriquez-Obregon G.A., Vasquez-Padron R.I., Prieto-Samsonov D.L., De la Riva G.A., Selman-Housein G., Herbicide-resistant sugarcane (Saccharum officinarum L.) plants by Agrobacterium-mediated transformation, Planta 206 (1998) 20-27.

[18] Harvengt L., Trontin J.F., Reymond I., Canlet F., Pâques M., Molecular evidence of true-to-type propagation of a 3-year-old Norway spruce through somatic embryogenesis, Planta 213 (2001) 828-832.

[19] Hodal L., Bochardt A., Nielsen J.E., Mattsson O., Okkels F.T., Detection, expression and specific elimination of endogenous $\beta$-glucuronidase activity in transgenic and non-transgenic plants, Plant Sci. 87 (1992) 115-122.

[20] Högberg K.A., Ekberg I., Norell L., Von Arnold S., Integration of somatic embryogenesis in a tree breeding programme: a case study with Picea abies, Can. J. For. Res. 28 (1998) 1536-1545.

[21] Jefferson R.A., Kavanagh T.A., Bevan M.W., GUS fusion: $\beta$-glucuronidase as a sensitive and versatile gene fusion marker in higher plants, EMBO J. 6 (1987) 3901-3907.

[22] Klein T.M., Wolf E.D., Wu R., Sanford J.C., High-velocity microprojectile for delivering nucleic acids into living cells, Nature 327 (1987) 70-73.

[23] Klimaszewska K., Devantier Y., Lachance D., Lelu M.A., Charest P.J., Larix laricina (tamarack): somatic embryogenesis and genetic transformation, Can. J. For. Res. 27 (1997) 538-550.

[24] Koncz C., Schell J., The promoter of TL-DNA gene 5 controls the tissue-specific expression of chimaeric genes carried by a novel type of Agrobacterium binary vector, Mol. Gen. Genet. 204 (1986) 383-396.

[25] Koukolikova-Nicola Z., Raineri D., Stephens K., Ramos C., Tinland B., Nester E.W., Hohn B., Genetic analysis of the virD operon of Agrobacterium tumefaciens: a search for functions involved in transport of T-DNA into the plant cell nucleus and in T-DNA integration, J. Bact. 175 (1993) 723-731.

[26] Kumar S., Fladung M., Controlling transgene integration in plants, Trends Plant Sci. 6 (2001) 155-159.

[27] Lambe P., Dinant M., Matagne R.F., Ledoux L., Genetic transformation of Nicotiana plumbaginifolia cells using a low-cost particle gun device, Arch. Int. Physio. Bioch. Bioph. 99 (1991) 12.

[28] Lelu M.A., Bastien C., Drugeault A., Gouez M.L., Klimaszewska K., Somatic embryogenesis and plantlet development in Pinus sylvestris and $\mathrm{Pi}$ nus pinaster on medium with and without growth regulators, Physiol. Plant 105 (1999) 719-728.

[29] Levée V., Lelu M.A., Jouanin L., Cornu D., Pilate G., Agrobacterium tumefaciens-mediated transformation of hybrid larch (Larix kaempferi $\times L$. decidua) and transgenic plant regeneration, Plant Cell Rep. 16 (1997) 680-685.

[30] Levée V., Garin E., Klimaszewska K., Séguin A., Stable genetic transformation of white pine (Pinus strobus L.) after cocultivation of embryogenic tissues with Agrobacterium tumefaciens, Mol. Breed. 5 (1999) 429-440.

[31] Mullin T.J., Park Y.S., Estimating genetic gains from alternative breeding strategies for clonal forestry, Can. J. For. Res. 22 (1992) 14-23.

[32] Odell J.T., Nagy F., Chua N.H., Identification of DNA sequences required for activity of the cauliflower mosaic virus $35 \mathrm{~S}$ promoter, Nature 313 (1985) 810-812.

[33] Ortiz J.P.A., Reggiardo M.I., Ravizzini R.A., Altabe S.G., Cervigni G.D.L., Spitteler M.A., Morata M.M., Elias F.E., Vallejos R.H., Hygromycin-resistance as an efficient selectable marker for wheat stable transformation, Plant Cell Rep. 15 (1996) 877-881.

[34] Park Y.S., Implementation of conifer somatic embryogenesis in clonal forestry: technical requirements and deployment considerations, Ann. For. Sci. 59 (2002) 651-656.

[35] Pilate G., Leplé J.C., Cornu D., Lelu M.A., Transgenic Larch (Larix species), in: Bajaj Y.P.S. (Ed.), Biotechnology in agriculture and forestry, Vol. 44, Transgenic trees, Sringer-Verlag, Germany, 2000, pp. 125-139.

[36] Ramarosandratana A., Harvengt L., Bouvet A., Calvayrac R., Pâques M., Effects of carbohydrate source, polyethylene glycol and gellan gum concentration on embryonal-suspensor mass (ESM) proliferation and maturation of maritime pine somatic embryos, In Vitro Cell. Dev. Biol. Plant 37 (2001) 29-34. 
[37] Ramarosandratana A., Harvengt L., Bouvet A., Calvayrac R., Pâques M., Influence of the embryonal-suspensor mass (ESM) sampling on development and proliferation of maritime pine somatic embryos, Plant Sci. 160 (2001) 473-479.

[38] Robert C.S., Rajagopal S., Smith L.A., Nguyen T.A., Yang W., Nugroho S., Ravi K.S., Cao M.L., Vijayachandra K., Patell V., Harcourt R.L., Dransfield L., Desamero N., Slamet I., Keese P., Kilian A., Jefferson R.A., A comprehensive set of modular vectors for advanced manipulations and efficient transformation of plants, Rockefeller Foundation Meeting of the International Program on Rice Biotechnology, Malacca, Malaysia, Sept. 15-19, 1997, (Poster).

[39] Sambrook J., Fritsch E.F., Maniatis T., Molecular cloning: a laboratory manual, 2nd ed., Cold Spring Harbor Laboratory Press, Cold Spring Harbor, NY, 1989.

[40] Smith D.R., Successful rejuvenation of radiata pine, in: 25th Southern Forest Tree Improvement Conference, New Orleans, July 11-14, 1999, pp. $158-167$.

[41] Stomp A.M., Histochemical localization of $\beta$-glucuronidase, in: Gallagher S.R. (Ed.), Gus protocols. Using the gus gene as a reporter of gene expression, Academic Press, San Diego, 1992, pp. 103-114.

[42] Sutton B., Commercial delivery of genetic improvement to conifer plantations using somatic embryogenesis, Ann. For. Sci. 59 (2002) 657-661.
[43] Tian L.M., Charest P.J., Séguin A., Rutledge R.G., Hygromycin resistance is an effective selectable marker for biolistic transformation of black spruce (Picea mariana), Plant Cell Rep. 19 (2000) 358-362.

[44] Timmis R., Bioprocessing for tree production in the forest industry: conifer somatic embryogenesis, Biotechnol. Prog. 14 (1998) 156-166.

[45] Von Aderkas P., Bonga J.M., Influencing micropropagation and somatic embryogenesis in mature trees by manipulation of phase change, stress and culture environment, Tree Physiol. 20 (2000) 921-928.

[46] Wagner A., Moody J., Grace L.J., Walter C., Transformation of Pinus radiata based on selection with hygromycin B, N. Z. J. For. Sci. 27 (1997) 280-288.

[47] Walter C., Grace L.J., Wagner A., White D.W.R., Walden A.R., Donaldson S.S., Hinton H., Gardner R.C., Smith D.R., Stable transformation and regeneration of transgenic plants of Pinus radiata D. Don, Plant Cell Rep. 17 (1998) 460-468.

[48] Walter C., Grace L.J., Donaldson S.S., Moody J., Gemmell J.E., van der Maas S., Kvaalen H., Lönneborg A., An efficient Biolistic transformation protocol for Picea abies embryogenic tissue and regeneration of transgenic plants, Can. J. For. Res. 29 (1999) 1539-1546.

[49] Wenck A.R., Quinn M., Whetten R.W., Pullman G., Sederoff R., High-efficiency Agrobacterium-mediated transformation of Norway spruce (Picea abies) and loblolly pine (Pinus taeda), Plant Mol. Biol. 39 (1999) 407-416.

To access this journal online: www.edpsciences.org 
